\title{
PENINGKATAN KEMAMPUAN MENYIMAK CERITA RAKYAT MENGGUNAKAN MEDIA PAPAN FLANEL DALAM MATA KULIAH MENYIMAK KARYA SASTRA DI IKIP BUDI UTOMO MALANG
}

\author{
Luly Zahrotul Lutfiyah \\ IKIP Budi Utomo Malang \\ E-mail : lulylutfiyah@gmail.com
}

\begin{abstract}
ABSTRAK: Penelitian bertujuan: (1) penerapan media papan flanel untuk meningkatkan kemampuan menyimak cerita rakyat, (2) keberhasilan media papan flanel dalam menentukan hal menarik dari unsur cerita rakyat (3) keberhasilan media papan flanel dalam menentukan hal menarik relevansi tema dengan situasi sekarang, (4) keberhasilan penggunaan media papan flanel menentukan hal menarik dalam cerita rakyat dengan alasan logis, (5) menggambarkan media papan flanel dalam meningkatkan kemampuan menyimpulkan pesan cerita rakyat. Jenis penelitian PTK. Media papan flanel dapat meningkatkan kemampuan menyimak mahasiswa kelas A angkatan 2014. Kegiatan siklus 1 dan 2 dibuktikan dengan skor kumulatif. Terjadi peningkatan tiap aspek. Pemahaman isi, siklus 1 sebesar $92 \%$ dan siklus 2 sebesar $80 \%$. Aspek edukatif siklus 1 skor $74 \%$ dan siklus 2 sebesar $61 \%$, aspek pembangun karakter siklus 1 skor $72 \%$ dan siklus 2 skor 74\%. Aspek mengungkapan hal menarik dengan alasan logis siklus 1 sebesar $64 \%$ dan siklus 2 sebesar 77\%. Aspek kesimpulan pesan siklus 1 sebesar $65 \%$ dan siklus 2 sebesar $89 \%$. Skor kumulatif siklus 1 sebesar $82 \%$ dan siklus 2 sebesar $70 \%$. Hasil observasi terjadi peningkatan. Kondisi pembelajaran lebih hidup. Minat mahasiswa besar. Saran untuk peneliti selanjutnya, sebaiknya meneliti penggunaan media flanel untuk meningkatkan aspek afektif mahasiswa.
\end{abstract}

Kata Kunci: keterampilan, menyimak, papan flannel

ABSTRACT: The research aims: (1) the application of flannel board media to improve the ability to listen to folklore, (2) the success of flannel board media in determining interesting aspects of folklore (3) the success of flannel board media in determining the relevance of the theme to the current situation , (4) the successful use of flannel board media determines interesting things in folklore for logical reasons, (5) describes the flannel board media in improving the ability to infer folklore messages. Type of CAR research. Flannel board media can improve the ability to listen to class A students of class 2014. Cycle 1 and 2 activities are proven by cumulative scores. An increase in each aspect. Content understanding, cycle 1 is $92 \%$ and cycle 2 is $80 \%$. Educative aspects of cycle 1 score $74 \%$ and cycle 2 by $61 \%$, aspect of character building cycle 1 scores $72 \%$ and cycle 2 scores 74\%. Aspects reveal interesting things with logical reasoning that cycle 1 is $64 \%$ and cycle 2 is $77 \%$. The conclusion aspect of the first cycle message is $65 \%$ and the second cycle is $89 \%$. Cumulative score of cycle 1 is $82 \%$ and cycle 2 is $70 \%$. Observation results have increased. The condition of learning is more alive. Great student interest. Suggestions for future researchers, should examine the use of flannel media to improve the affective aspects of students.

Keywords: skills, listening, flannel board 
Menyimak digunakan dalam segala aktivitas kehidupan manusia. Tarigan (1994:2) menyatakan bahwa keterampilan berbahasa (language arts, language skills) memiliki empat unsur, yaitu 1) menyimak (listening skills), 2) berbicara (speaking skill), 3) membaca (reading skills) dan 4) menulis (writing skills). Menyimak merupakan keterampilan berbahasa awal yang harus dikuasai oleh manusia. Keterampilan menyimak perlu dikuasai oleh mahasiswa secara efektif dan efisien. Meskipun demikian, dalam pelaksanaan pembelajaran di sekolah penguasaan terhadap ketrampilan menyimak pada umumnya masih diabaikan, termasuk menyimak cerita rakyat. Penyebab pengabaian pembelajaran ketrampilan tersebut adalah mahasiswa menganggap pembelajaran menyimak cerita rakyat merupakan pembelajaran yang mudah dilakukan sehingga mereka tidak antusias terhadap pembelajaran. Mahasiswa menganggap keterampilan menyimak cerita rakyat adalah kegiatan yang menyenangkan. Hal tersebut mengakibatkan keterampilan menyimak kurang dikuasai dengan baik. Padahal, penguasaan keterampilan berbahasa yang lain: membaca, berbicara dan menulis, penyampaiannya dengan proses menyimak.

Kegunaan penelitian ini untuk mengembangkan teori pembelajaran keterampilan menyimak karya sastra bahasa Indonesia sehingga dapat meningkatkan kualitas hasil pembelajaran dan mutu pendidikan pada umumnya. Penggunaan media papan flannel ini diharapkan kegiatan pembelajaran lebih inovatif. Hasil belajar mahasiswa dalam pembelajaran keterampilan menyimak cerita rakyat dapat meningkat. Manfaat penelitian dosen 1) memperbanyak wawasan media pembelajaran, terlebih dalam pembelajaran keterampilan menyimak cerita rakyat; 2) melengkapi media pembelajaran yang selama ini digunakan; dan 3) membuat kegiatan belajar mengajar lebih menarik sehingga mahasiswa tidak merasa bosan. Manfaat bagi mahasiswa, yaitu 1) membantu mahasiswa dalam mengatasi kesulitan khususnya pembelajaran keterampilan menyimak, memotivasi mahasiswa untuk belajar 
lebih giat; dan (3) melatih serta membiasakan mahasiswa melakukan kegiatan menyimak secara efisien dan efektif.

\section{MEDIA}

Dalam Kamus Besar Bahasa

Indonesia (1994:726) dijelaskan

bahwa Media adalah alat yang

dipakai sebagai saluran

menyampaikan pesan/informasi dari sumber kepada penerimanya. Fungsi media untuk tujuan instruksi di mana informasi yang terdapat pada media harus melibatkan peserta didik baik dalam benak atau mental dalam bentuk aktivitas yang nyata, sehingga kegiatan pembelajaran dapat terjadi (Arsyad 1997:21). Bisa disimpulkan media merupakan alat untuk menyampaikan informasi dari sumber informasi kepada penerima. Jadi, media dalam kegiatan pembelajaran merupakan sarana untuk menyampaikan informasi tentang kegiatan pembelajaran dari dosen kepada mahasiswa.

Papan flanel merupakan salah satu media grafis yang dapat digunakan untuk menyajikan pesan kepada sasaran. Media papan flanel dapat dibuat dengan kreatifitas mahasiswa. Bahan yang akan digunakan dapat dipasang dan dicopot dengan mudah sehingga dapat dipakai berkali-kali. Papan flanel termasuk salah satu media pembelajaran dua dimensi, yang dibuat dari kain flanel yang ditempelkan pada sebuah triplek atau papan.

\section{METODE PENELITIAN}

Penelitian ini merupakan penelitian kualitatif interaktif. Jenis penelitiannya menggunakan PTK (Penelitian Tindakan Kelas). Arikunto (2006: 58) menyatakan penelitian tindakan kelas adalah penelitian tindakan (Action Research) yang dilakukan bertujuan memperbaiki mutu praktek pembelajaran di kelas.

Kegiatan penelitian ini dilaksanakan pada mahasiswa kelas A angkatan 2014 IKIP Budi Utomo Malang. Peneliti memilih penelitian di IKIP Budi Utomo Malang karena peneliti mengajar di IKIP Budi Utomo Malang. Peneliti menemukan masalah aktivitas mahasiswa kurang begitu terlihat dalam pembelajaran, daya ingatnya kurang dan hasil belajarnya juga banyak yang di 
bawah SKM (Standar Ketuntasan Minimal). Seperti contohnya dalam pembelajaran menyimak karya sastra berupa cerita rakyat. Pemahaman siswa dalam menyimak cerita rakyat masih sangat rendah. Selain itu, di IKIP Budi Utomo Malang belum pernah dilakukan penelitian tentang penggunaan media pembelajaran papan flanel.

\section{HASIL PENELITIAN}

Temuan hasil evaluasi pada siklus 1 dan pada siklus 2, terdapat skor kumulatif dari tiap aspek yang dinilai dari keterampilan menyimak cerita rakyat. Unsur intrinsik untuk pemahaman isi siklus 1 memperoleh skor $84 \%$ siklus $292 \%$ sehingga terjadi peningkatan sebesar $9 \%$. Unsur kemenarikan cerita rakyat siklus 1 diperoleh skor $64 \%$ pada siklus 2 sebanyak $71 \%$ sehingga terjadi peningkatan sebesar $6 \%$, aspek relevansi cerita rakyat siklus 1 diperoleh skor sebesar $72 \%$, siklus 2 74\% terdapat peningkatan sebesar $1 \%$, aspek pembangun karakter cerita rakyat siklus 1 diperoleh persentase skor sebesar $76 \%$ dan siklus 2 sebesar $87 \%$ sehingga diperoleh kenaikan sebesar $12 \%$, aspek pesan cerita rakyat siklus 1 diperoleh persentase skor sebesar $76 \%$ dan siklus 2 sebesar $82 \%$ sehingga diperoleh kenaikan sebesar 6\%, skor kumulatif siswa siklus 1 diperoleh skor sebanyak $74 \%$ siklus 2 sebesar $82 \%$ sehingga memperoleh kenaikan sebesar $8 \%$.

Dari kegiatan observasi juga terdapat peningkatan, kegiatan pembelajaran di kelas menjadi lebih kreatif dan inovatif. Mahasiswa lebih semangat dengan papan flanel yang dikerjakan dengan kreatifitas mahasiswa untuk alat menyampaikan isi cerita rakyat yang disimak. Antusiasme mahasiswa pada kegiatan menyimak cerita rakyat cukup besar. Dari kegiatan penelitian ini dapat diperoleh temuan yaitu penerapan media papan flanel dapat meningkatkan keterampilan mahasiswa pada kegiatan menyimak cerita rakyat.

\section{PEMBAHASAN}

Penerapan Media Papan Flanel dalam Meningkatkan Kemampuan Menyimak Cerita Rakyat pada Mata Kuliah Menyimak Karya Sastra di IKIP Budi Utomo Malang

Berdasarkan hasil tes pratindakan menunjukkan bahwa 
tingkat kemampuan menyimak karya sastra mahasiswa masih rendah. Mahasiswa kesulitan menemukan hal menarik dari cerita rakyat yang meliputi unsur tokoh, tema, watak, dan latar cerita rakyat yang diperdengarkan, menunjukkan hal menarik tentang relevansi cerita rakyat dengan kondisi saat ini, menemukan hal menarik dalam cerita rakyat yang diperdengarkan, dan menyampaikan pesan dari cerita rakyat yang disimak. Kegiatan yang dilakukan dosen dengan memberikan bahan cerita kepada mahasiswa untuk dibaca. Selain itu belum ada media yang digunakan dosen. Perlu adanya solusi melalui peningkatan inovasi media pembelajaran. Dengan adanya penerapan media baru, yaitu media yang terbuat dari Papan Flanel.

Dengan media ini, membuat mahasiswa IKIP Budi Utomo merasa senang dan semangatnya meningkat serta dapat menghilangkan kebosanan dalam mengikuti pembelajaran. Langkah-langkah dalam pembuatan media papan flanel ini disesuaikan dengan imajinasi mahasiwa. Pertama, memulai dari bagian memberi kebebasan kepada mahasiswa untuk berkreasi. Kedua, menggunakan gambar dari papan flanel, karena gambar membuat lebih menarik, membuat mahasiswa fokus, berkonsentrasi dan mengoptimalkan otak. Ketiga, komposisi warna papan flannel. Warna bagi otak, sama menariknya dengan gambar, menambah energi kepada pemikiran kreatif, dan menyenangkan. Setelah langkah-langkah tersebut selesai, mahasiswa melaporkan hasilnya di depan kelas dan mahasiswa yang lain bisa memberikan tanggapan, saran, masukan, apabila masih terdapat kekurangan. Dengan demikian, penelitian ini menerapkan media papan flanel untuk pembelajaran menyimak cerita rakyat di kelas A, yang diterapkan 2 siklus. Kegiatan penelitian ini membuktikan bahwa dalam pelaksanaan pembelajaran sangat diperlukan ketepatan dalam pemilihan materi dan media yang sesuai serta perencanaan pelaksanaan pembelajaran dapat mempengaruhi proses belajar mengajar. Dengan adanya pemilihan yang tepat, akan membuat pembelajaran bermakna bagi siswa.

Penerapan Media Papan Flanel dalam Peningkatan Kemampuan Menentukan Unsur Intrinsik 
Cerita rakyat yang Meliputi Tokoh, Watak, Tema, Latar Cerita rakyat

Berdasarkan hasil temuan, ditemukan bahwa peningkatan terjadi pada aspek menentukan unsur intrinsik cerita rakyat yang meliputi tokoh, watak, tema dan latar di siklus 1 diperoleh skor sebesar $74 \%$ dan pada siklus 2 sebesar $81 \%$ sehingga terjadi peningkatan sebesar 6\%.

Aspek yang meningkat pada pembelajaran ini dikarenakan adanya perbaikan yang dilaksanakn setiap pembelajaran. Aspek unsur terjadi peningkatan kemampuan menyimak cerita rakyat diperoleh dari pengetahuan awal yang dimiliki oleh mahasiswa. Kompetensi dasar sebelum menyimak cerita rakyat, pembelajaran yang diperoleh mahasiswa pada cerita rakyat dalam kegiatan membaca, sehingga mahasiswa termitivasi untuk unsur cerita rakyat, yaitu tokoh, watak, tema dan latar. Peran media papan flanel yang dibuat mahasiswa akan memudahkan mahasiswa untuk menjawab soal evaluasi yang berkaitan dengan unsur intrinsic cerita rakyat yang meliputi tokoh, watak, tema dan latar.

\section{Penerapan Media Papan Flanel dalam Meningkatkan Kemampuan Menunjukkan Karakter Budi Pekerti dalam Cerita Rakyat Relevansi Tema dengan Situasi Sekarang}

Berdasarkan hasil temuan lengkap diketahui bahwa telah terjadi peninghkatan persentase skor pada aspek menunjukkan karakter budi pekerti dalam cerita rakyat dengan situasi sekarang. Pada siklus 1 mendapat skor sebesar $72 \%$ dan pada siklus 2, $84 \%$ sehingga terjadi kenaikan sebesar 12\%. Hal ini disebabkan oleh pengetahuan mahasiswa terhadap aspek budi pekerti dalam cerita rakyat kurang bisa mengaplikasikannya dengan situasi sekarang. Sebagian mahasiswa masih bingung dalam menjelaskan kemenarikan hubungan tema dengan kehidupan sekarang, misalnya saja menentukan hal-hal ajaib/ aneh dalam cerita rakyat terjadi dalam kehidupan saat ini, sebagian mahasiswa mengalami kesulitan menunjukkan relevansi keajaiban/keanehan itu terjadi dalam kehidupan sehari-hari, sebagian mahasiswa mengalami kesulitan 
menunjukkan relevansi nilai-nilai yang ada dalam cerita rakyat tersebut masih sesuai atau tidak jika diterapkan dalam kehidupan sekarang.

Penerapan Media Papan Flanel dalam Meningkatkan Kemampuan Mengungkapan Hal-hal Menarik Dalam Cerita rakyat yang Disimak dengan Alasan yang Logis

Berdasarkan hasil temuan
lengkap diketahui bahwa
peningkatan yang terjadi pada
pengungkapan hal yang menarik
pada cerita rakyat dengan alasan
yang logis di siklus 1 memperoleh
persentase skor $84 \%$ dan siklus 2
sebesar 92\% sehingga memperoleh
kenaikan sebesar 13\%.

Pada aspek mengungkapan hal-hal menarik dalam cerita rakyat dengan alasan yang logis mahasiswa tidak terlalu kesulitan. Namun, mahasiswa perlu menemukan alasan untuk memahami dan memberi alasan sesuai dengan hal yang menarik. Dosen berusaha memberi contoh yang melibatkan mahasiswa. Sebagai contoh dosen memberikan dua jenis judul cerita rakyat Manggarai dan cerita rakyat Banyuwangi yang dikemas dalam bentuk media media papan flanel untuk memudahkan mahasiswa menjawab soal evaluasi khususnya tentang aspek mengungkapkan hal menarik dalam cerita rakyat yang disimak.

\section{Penerapan Media Papan Flanel dalam Meningkatkan Kemampuan Menyimpulkan Pesan Cerita rakyat}

Pada aspek ini, peningkatan kemampuan mahasiswa dalam menyimak cerita rakya juga mengalami peningkatan terutama dalam menentukan ungkapan. Contoh makna yang menjadi anggotanya (makna kambing hitam tidak sama dengan makna kambing atau hitam). Ungkapan banyak digunakan dalam berbagai cerita atau percakapan tidak resmi.

Berdasarkan hasil temuan lengkap diketahui bahwa peningkatan yang terjadi pada empat aspek tersebut skor kumulatif mahasiswa di siklus 1 terdapat persentase skor $82 \%$ dan siklus 2 sebesar $88 \%$ sehingga memperoleh kenaikan sebesar $6 \%$.

Dari data diatas peningkatan skor rata-rata tiap siklus dan skor kumulatif terbukti bahwa pembelajaran menyimak cerita rakyat dengan menggunakan media 
IKIP Budi Utomo Malang

papan flanel dapat meningkatkan kreativitas mahasiswa pada kegiatan menyimak dan berpengaruh pada penguasaan kemampuan menyimak cerita rakyat.

\section{Kesimpulan}

Pelaksanaan penelitian tindakan Kelas tentang pembelajaran dengan media papan flanel untuk meningkatkan kemampuan menyimak cerita rakyat. Menemukan hal yang menarik dari cerita rakyat yang diperdengarkan kelas A angkatan 2014 IKIP Budi Utomo Malang dapat disimpulkan, penerapan media papan flanel dalam pembelajaran menyimak cerita rakyat menemukan hal-hal yang menarik dari cerita rakyat yang diperdengarkan di kelas A angkatan 2014 IKIP Budi Utomo Malang dilakukan dengan cara, menyimak cerita rakyat yang diberikan oleh dosen dari media papan flanel.

Media papan flanel mampu meningkatkan kemampuan menyimak cerita rakyat siswa kelas A angkatan 2014 IKIP Budi Utomo Malang. Dari kegiatan pada siklus 1 dan pada siklus 2 terdapat skor kumulatif sehingga terjadi peningkatan masing-masing aspek. Berdasarkan hasil observasi juga terjadi peningkatan, kegiatan pembelajaran lebih kreatif dan inovatif. Situasi kelas dapat dikendalikan, mahasiswa merasa senang dengan media papan flanel cerita rakyat yang dimanfaatkan sebagai media untuk menyimak cerita rakyat. Minat mahasiswa cukup besar dalam mengikuti kegiatan menyimak cerita rakyat.

\section{Saran}

Dari hasil penelitian pendeskripsian penerapan media papan flanel dapat meningkatkan kemampuan menyimak cerita rakyat mahasiswa kelas A angkatan 2014 IKIP Budi Utomo Malang. Oleh karena itu, peneliti memberikan saran kepada dosen, guru, kepala sekolah, dan peneliti lain. Saran tersebut dapat diuraikan sebagai berikut: Hendaknya dosen dapat: (a) Menerapkan media papan flanel sebagai variasi kreatifitas metode pembelajaran agar mahasiswa tidak bosan dalam kegiatan pembelajaran, (b) Pemilihan media pembelajaran yang sesuai dalam penyampaian matakuliah menyimak karya sastra, 
Prodi Pendidikan Bahasa dan Sastra Indonesia

IKIP Budi Utomo Malang

sehingga dapat meningkatkan

kualitas mata kuliah menyimak karya

sastra, (c) meningkatkan

pengetahuan mahasiswa, maka

mahasiswa diberikan kegiatan tindak

lanjut untuk menyusun catatan

menggunakan media papan flanel

untuk pembelajaran berikutnya.

Keterbatasan penelitian ini adalah

penerapan media papan flanel pada

penelitian ini dikhususkan pada

penilaian aspek kognitif dan

psikomotor saja. Sehingga

disarankan bagi peneliti lanjut, coba

meneliti penerapan media papan

flanel dalam upaya untuk

meningkatkan aspek afektif siswa.

\section{DAFTAR RUJUKAN}

Arikunto, S. 2009. Penelitian

Tindakan Kelas. Jakarta: Bumi

Angkasa.

Arsyad, A. 1997. Media Pembelajaran.

Jakarta: Rajagrafindo Putra

Utama.

Tim Penyusun Pusat Kamus. 2007.

Kamus Besar Bahasa Indonesia.

Jakarta: Balai Pustaka.

Tarigan, H. G. 1994. Menyimak Sebagai

Suatu Keterampilan Berbahasa.

Bandung: Angkasa. 